\title{
Communicative language teaching approach in the development of speaking skill
}

\author{
Enfoque comunicativo de enseñanza del lenguaje para el desarrollo de la \\ habilidad del habla
}

Nataly Giovanna Oviedo Guado. ${ }^{1} \&$ Jazmina Ivonne Mena Mayorga. ${ }^{2}$

\begin{abstract}
.
DOI: https://doi.org/10.33262/cienciadigital.v5i4.1865

Introduction. Oral communication is perhaps the most important skill while learning a foreign language. The conventional English teaching method that is applied at the different educational levels based on grammar and writing, does not allow the development of the necessary communication skills. The communicative teaching of language has been the subject of this research, in which its effectiveness has been treated using different resources and skills. Objective. This research aims to apply communicative language teaching activities to determine its effectiveness in the development of the speaking skill, in the second-year of Bachelor Education in a secondary institution in Riobamba, Ecuador. Methodology. A field, descriptive, prospective, longitudinal, quasi-experimental and quantitative research was carried out. The universe was made up of 94 students at that level. The sample equivalent to the universe was organized into two groups, one experimental and one control, with 47 students each. A diagnostic examination and a final test were applied for both groups,
\end{abstract}

\footnotetext{
${ }^{1}$ Pontificia Universidad Católica del Ecuador - Sede Ambato, Maestría en Pedagogía del Inglés como Lengua Extranjera, Tungurahua, nataly.g.oviedo.g@ pucesa.edu.ec,https://orcid.org/0000-0003-10456581

${ }^{2}$ Pontificia Universidad Católica del Ecuador - Sede Ambato, Maestría en Pedagogía del Inglés como Lengua Extranjera, Tungurahua, jazmin_menamayorga@hotmial.com, https://orcid.org/0000-0002-50735967
} 
which during the time between both tests, followed different teaching-learning approaches. In the control group the traditional method was applied and in the experimental group, the communicative approach to language teaching. Results. The results showed that although both groups improved their performance in speaking, in the experimental group the increase in speaking ability was greater than in the control group. Conclusion. It was concluded that the application of communicative language teaching activities was effective in development of the speaking skill.

Keywords: language teaching, active teaching methodologies, communicative skills assessment, collaborative learning, communicative competence.

\section{Resumen.}

Introducción. La comunicación oral es quizás la habilidad más importante al aprender una lengua extranjera. El método convencional de enseñanza del inglés que se utiliza en los niveles educacionales, basado en la gramática y la escritura no permite el desarrollo de las habilidades comunicativas necesarias. La enseñanza comunicativa del lenguaje ha sido objeto de investigaciones, en las que se ha tratado su eficacia mediante el uso de diferentes recursos y habilidades. Objetivo. Esta investigación tiene como objetivo aplicar las actividades de la enseñanza comunicativa del lenguaje para determinar su efectividad en el desarrollo de la habilidad del habla en estudiantes de segundo año de bachillerato de la Unidad Educativa Salesiana "Santo Tomás Apóstol", en Riobamba, Ecuador. Metodología. Se realizó una investigación de campo, descriptiva, prospectiva, longitudinal, cuasi experimental y cuantitativa. El universo estuvo conformado por los 94 estudiantes de ese nivel. La muestra equivalente al universo, se organizó en dos grupos, uno experimental y otro de control, con 47 estudiantes cada uno. Se aplicó un examen diagnóstico inicial y una prueba final para ambos grupos, que durante el tiempo entre ambos test, siguieron enfoques de enseñanza aprendizaje diferentes. En el grupo de control se aplicó el método tradicional y en el grupo experimental, el enfoque comunicativo de enseñanza del lenguaje. Resultados. Los resultados mostraron que aunque ambos grupos mejoraron su desempeño en la expresión oral, en el grupo experimental el incremento de la habilidad del habla fue mayor que para el grupo de control. Conclusión. Se llegó a la conclusión de que las actividades interactivas aplicadas, como los diálogos, los juegos de roles y el intercambio de información, fueron efectivas para desarrollar la destreza en el habla de los estudiantes.

Palabras claves: enseñanza de la lengua, metodologías activas de enseñanza, evaluación de habilidades comunicativas, aprendizaje colaborativo, competencia comunicativa.

\section{Introduction.}

The globalization process has influenced all aspects of society in the world (Chávez et al., 2017). Learning a second language is necessary not only for daily live situations but also to improve professionally (Veloz \& Mancero, 2017), (Chávez et al., 2017). English is the 
universal language, and it is learned by people all over the world (Veloz \& Mancero, 2017). It is considered "lingua franca" because it is present in most of the literature and audiovisual materials in the world (Aristizabal et al., 2020), (Chávez et al., 2017). That is why it is necessary to take advantage of the teaching at all educational levels to achieve the English learning in an integral way. Also, for the development of the four basic skills: reading, writing, listening and speaking (Veloz \& Mancero, 2017).

Although the Ministry of Education in Ecuador established by a resolution in 2014 the study of English from the second grade of Basic General Education to the third year of Bachelor Education and the State has allocated resources to improve the way of teaching English through training and educational programs for teachers, learning does not reach the desired levels (Barrera \& Barragán, 2017), (Fabre et al., 2016), (Sánchez \& Pérez, 2020). In 2016, the English curriculum was refined considering the communicative teaching approach as its main aspect (Toro et al., 2019).

The Common European Framework of Reference (CEFR), which emerged in 2002, unified the way of organizing teaching to achieve communication in English for students in the region and it has been adopted as valid in other parts of the world (Castro et al., 2016). It established six levels of learning, indicated with the letters A (elementary level) B (intermediate level) and C (advanced level) and stages 1 and 2 for each one (Castro et al., 2016).

However, most of the teachers in Ecuador do not have the necessary language skills established by the B2 level (Castro et al., 2016), (Barrera \& Barragán, 2017). There is no national strategy to teach English (Castro et al., 2016), (Toro et al., 2019). The approach applied is based on the study of grammar, writing and reading comprehension, so students do not feel motivated and do not acquire enough oral and listening skills (Loor et al., 2018), (Barrera \& Barragán, 2017), (Toro et al., 2019), (Halbach, 2019).

It is known that human beings are prepared to speak before they learn to read or write, but oral expression is the most difficult skill to acquire, once they have passed childhood and the language of origin has been learned (Leong \& Masoumeh, 2017), (Toro et al., 2019). This is also due to the low levels of development of this skill at schools. Students feel more confident when reading or writing but speaking is difficult for them, since teachers do not apply strategies to create these skills (Toro et al., 2019). However, if someone is not able to speak, it is considered that they do not have command of the language (Farabi et al., 2017).

It is necessary to modify the approaches and strategies applied in teaching (Castro et al., 2016). Teachers, in addition to training, must use innovative ways that put into practice methods that allow students to understand, interact and achieve the curriculum standards established in English programs in Ecuador (Castro et al., 2016), (Fabre et al., 2016), (Sánchez \& Pérez, 2020). The communicative approach, which emerged since the 70s of the last century, is the way of teaching the language that has predominated for the last 30 years in the world and it is proposed as an effective way for the development of 
communication skills in students (Abreus \& Haro, 2019), (Castro et al., 2016), (Carrera \& Saulo, 2015).

The Salesian Educational Unit "Santo Tomás Apóstol" in Riobamba, is not an exception in Ecuador. Although students have received English as a subject in previous years, most of them do not use English in a conversation in the class and they prefer to do it in Spanish for several reasons: inhibition, embarrassment, lack of knowledge or interest in the topic, insufficient vocabulary, too many students in the class group and comfort to speak the mother tongue (Leong \& Masoumeh, 2017). The teacher must take them into account to work consciously. In the last four years, the Content and Language Integrated Learning (CLIL) approach has been applied in this educational center, using Cambridge materials. This approach has two objectives, learning the language and acquiring knowledge and culture about the matters that are used to classes support (Reyes et al., 2020). CLIL is considered as one of the most effective in the development communicative skills (Pinto, 2019). Although it can be more motivating for the student than the traditional method, it requires an accurate methodology from the teacher so that the language serves as a vehicle for content, which is not always achieved (Halbach, 2019). Consequently, students continue without developing the necessary communication skills.

But there is motivation on the part of some teachers and students to implement different forms of teaching English that promote oral expression. That is why it is necessary to try another approach that takes advantage of the motivation that exists in learners and teachers for the development of this skill. With the hypothesis that the application of the Communicative Language Teaching approach can be an effective tool in the development of speech skills in high school students, a research was carried out.

The research aims to apply the Communicative Language Teaching activities in the development of the speaking skill in second-year students in Bachelor Education at the Salesian Educational Unit "Santo Tomás Apóstol." Specifically, the research aims to define the Communicative language teaching approach and the speaking skills, to determinate the effectiveness of Communicative Language Teaching activities in the development of the speaking skills and to identify if students' response towards communicative language teaching activities is favorable.

\section{Theorical Framework}

Communication is the process by which ideas are sent and received (Parrales et al., 2018). In the communicative approach, it takes special importance since communication, together with the activity that emerges from it, is the basis of the teaching-learning process (Castro-Miranda et al., 2018). Communication is language (Richards \& Rodgers, 2014). Language skills are the ways in which the use of language manifests itself and are the four basic abilities.

Communicative language teaching (CLT) is the whole of principles and objectives to allow learning language using the classroom activities that best facilitate the development of the communicative competence (Richards, 2006). The methodological principles of 
CLT are: to produce a real communication in a real context; be tolerant with learner's mistakes, since he must develop his communicative competence by himself; provide him opportunities to develop accuracy and fluency; achieve the learning of the four basic language skills in a comprehensive and simultaneous way and ensure that the student is able to induce the rules of grammar. These principles should rule the teaching of the language and classroom activities.

Communicative competence is the ability to transmit coherent and organized oral and written information (Almanza et al., 2019). Speaking skill is the communicative process of exchanging ideas and feelings in a given context and in such a way that they are understood (Beltrán, 2018). So, the speaking skill is oral communicative competence. Developing this skill allow to speak fluently and accurately (Beltrán, 2018). Richards considers that communicative language teaching aims to develop the main sub-skills, fluency and precision, through the practice of interactive activities (Richards, 2006). Fluency occurs when the speaker can maintain a comprehensible communication without interruptions despite his limitations. That is possible if a communicative strategy is applied. The accuracy is the ability to use the correct form of language and intonation and it has to do with grammatical aspects. Accuracy support grammar learning from communicative approach. Fluency and accuracy training by these appropriate classroom activities, conduces to develop other sub-skills, like pronunciation, vocabulary and interaction (Beltrán, 2018). Speaking skill can support the language sub-skills and mutually, the training of these skills can improve speaking skill.

Richards proposes several types of activities that allow the development of sub-skills (Richards, 2006). Fluency can be developed through role plays, as these allow students to express themselves freely and with completely improvised language. Dialogues are activities that develop accuracy. This author refers other activities that promote the development of oral expression such as information-gap, information-gathering, opinionsharing, and task-completion. Information-gap activities are related to the exchange of necessary information.

For these, students can be organized into two groups, each with a part of the information, so that they have to interact with each other to obtain the information they need. In information-gathering activities, students conduct interviews, survey and search for information. The opinion-sharing activities, aims to make judges and analysis about a subject. Task-completion activities consist on completing information. All these types of activities develop the four basic skills and involves an effort from the student to produce the language in real contexts (Quiñonez, 2016).

The communicative competence must be used to different purposes and functions at formal and informal situations in a real context (Richards, 2006). It is not only about developing speech, but also writing in the form of text production (Almanza et al., 2019). But in addition, listening and understanding are skills associated with these processes, where the role of the person who speaks or writes and the person who listens or understands is continually exchanged between the interlocutors (Leong \& Masoumeh, 
2017). The interwoven of the four basic skills language develop the associated sub-skills such as knowledge of vocabulary, spelling, pronunciation, syntax, meaning and usage (Oxford, 2001). The teaching of all these abilities leads to optimal learning, which is known as the integrated-skill approach (Oxford, 2001). That is why the communicative approach must be applied on a broad sense, so that the student acquires the four basic skills (Quiñonez, 2016).

Table 1 shows a comparison between Traditional method and Communicative language teaching regarding the main learning objectives and other differences.

Table 1. Traditional and Communicative language teaching approaches differences.

\begin{tabular}{|c|c|c|}
\hline & Traditional method & Communicative language teaching \\
\hline $\begin{array}{l}\text { Main } \\
\text { objective }\end{array}$ & Grammatical competence & Communicative competence \\
\hline $\begin{array}{l}\text { Grammar } \\
\text { approach }\end{array}$ & $\begin{array}{l}\text { Deductive (repetitive practice } \\
\text { and memorization) }\end{array}$ & Inductive (productive practice) \\
\hline $\begin{array}{l}\text { Roles of } \\
\text { teacher and } \\
\text { student }\end{array}$ & $\begin{array}{l}\text { Focus on the teacher and the } \\
\text { knowledge to transmit. The } \\
\text { student is a passive learner. }\end{array}$ & $\begin{array}{l}\text { Focus on the student, as an active } \\
\text { learner, who must produce his own } \\
\text { knowledge by relationship with the } \\
\text { classroom mates. The teacher } \\
\text { facilitate, guide and monitoring the } \\
\text { learning process. }\end{array}$ \\
\hline Main skills & Writing and reading & $\begin{array}{l}\text { Speaking and listening mainly, but } \\
\text { also writing and reading }\end{array}$ \\
\hline $\begin{array}{l}\text { Main sub- } \\
\text { skills }\end{array}$ & $\begin{array}{l}\text { Vocabulary } \\
\text { Comprehension / translation }\end{array}$ & $\begin{array}{l}\text { Fluency } \\
\text { Accuracy } \\
\text { Vocabulary } \\
\text { Pronunciation } \\
\text { Interaction / comprehension }\end{array}$ \\
\hline $\begin{array}{l}\text { Classroom } \\
\text { activities }\end{array}$ & $\begin{array}{l}\text { Activities to do by the student } \\
\text { individually (reading texts, } \\
\text { answer written questions, filling } \\
\text { blank spaces exercises). }\end{array}$ & $\begin{array}{l}\text { Interactive activities between pairs or } \\
\text { groups of students that cooperate to } \\
\text { each other (produce dialogues, role- } \\
\text { play, information-gap, task- } \\
\text { completion, information-gathering } \\
\text { and opinion-sharing activities). }\end{array}$ \\
\hline $\begin{array}{l}\text { Classes } \\
\text { subject }\end{array}$ & $\begin{array}{l}\text { Literature and book text } \\
\text { contents. }\end{array}$ & $\begin{array}{l}\text { Daily`s live situations that involve to } \\
\text { students (real context). }\end{array}$ \\
\hline
\end{tabular}

Developed by: The author (based on information obtained from Communicative Language Teaching Today, by Richards, J.)

Communicative approach, due to its particularities, results more motivating for the students than Traditional method, hence the learning is facilitated (Beltrán, 2018). Communicative approach aims to practice the knowledge acquired in the classroom in everyday situations (Escalona et al., 2020). The subjects of the classes must be related to aspects of the students' daily life. So that, it is necessary for the teacher to know the 
student's context, their preferences and interests in order to introduce them to learning English (Pinto, 2019).

The roles of teacher and learner change regarding to the traditional method (Richards, 2006). The student became an active agent, as the center of learning-teaching process, thus increasing the level of learning, personal growth and skills for the development of speech (Loor et al., 2018), (Fuertes, 2017). Instead of the traditional lessons taught by the teacher, interactive activities are carried out in duos or groups, focused on the student, which reduces their stress and creates a positive environment for learning (Loor et al., 2018). The teacher facilitates guides and monitors the process (Loor et al., 2018), (Nofuentes, 2019).

Communicative approach uses several learning methods, among which are cooperative and task-based (Quiñonez, 2016), (Nofuentes, 2019). Some authors call the union of these methods an eclectic approach (Fuertes, 2017). They must be supported by appropriate and well-selected instructional materials (Richards, 2006). Its effective application depends on the practice of three principles: communication, associated with the development of specific tasks or roles, in contexts of interest and with meaning for the learner (Richards \& Rodgers, 2014).

Cooperative learning is an innovative mode that adapts to this approach, since it is based on the creation of collective knowledge, through multidirectional communicative interaction between students and with the teacher (Loor et al., 2018). This increases the opportunity for each student to put their communication skills into practice, so the participation of everyone in the classroom should be encouraged, as the best place to express themselves in the language (Beltrán, 2017), (Escalona et al., 2020). But it also considers independent and individual study as an important and necessary part of learning (Carrera \& Saulo, 2015).

Similarly, task-based learning is another way to favor exchange and communication, as it involves the student in class discussions, role-playing and others. It arose in the 80s of the 20th century, as a branch of the communicative approach and it is based on a succession of tasks about a specific topic (Nofuentes, 2019). Tasks are classified as realworld and pedagogical (Richards, 2006). The real-world tasks are associated with interactive activities and the pedagogical tasks have to do with the ways in which the content learning mode is produced (Arcila \& Velazco, 2016).

\section{Methodology.}

\section{Research, universe and sample.}

Between September 2020 and March 2021, a field, descriptive, prospective, longitudinal, quasi-experimental and quantitative research was developed. That is why the research was carried out over time, with measurements of variables at two different moments to determine the effect produced on the development of oral skills, in students after applying the CLT activities (Calderón \& Alzamora, 2018). 
The universe was made up of 94 students of that level. The sample, equivalent to the universe, was organized into two groups, one experimental and one controlled, with 47 students each.

The course had the same objectives according to the teaching level and the same evaluations were applied to both study groups. Each study group carried out the course following different teaching-learning methods or approaches. Both groups had 40 minutes classes two times a week to carry out the planned activities of the course, using the traditional teaching method, based on the analysis of grammar rules, vocabulary and text comprehension (Richards \& Rodgers, 2014), (Sánchez \& Pérez, 2020). The written work prevailed over the oral. In addition, a monthly meeting was arranged with both groups, with the same content and didactic material for the classes. The control group used in these meetings the Traditional teaching-learning method. But the experimental group used the Communicative Language Teaching approach and its interactive and productive language activities on real context, such as dialogues, role play and information-gap. This way it was created an interactive environment between the students in the classroom in order to develop the communicative competence.

The sequence of activities within these classes was in general the following: student's presentation of the outcome of the independent work oriented in the previous meeting, teacher's presentation of the lesson's topic with the support of didactic materials, a presentation by the teacher of the tasks to be carried out by the students on the basis of the topic, elaboration of tasks by the students in each team, presentation of oral and written results, general discussion, evaluation of the activity with the students and orientation of independent team work. This sequence of tasks was proposed by different authors, except that regard to independent work (Willis \& Willis J., 2013), (Richards \& Rodgers, 2014), (Fuertes, 2017). But independent work was added as an important complement to cooperative learning (Carrera \& Saulo, 2015).

\section{Instruments and variables.}

Evaluation is the most effective instrument to measure the educational results of students, that is why it has been used in several researches to measure the effectiveness of the application of the communicative approach (Carrera \& Saulo, 2015), (Arcila \& Velazco, 2016), (Marañón et al., 2018), (Escalona et al., 2020). So, an initial diagnosis (pre-test) similar to the Cambridge PET (Preliminary English Test) for A1 level was applied, in correspondence with the knowledge that students should have reached in the previous course. To finish the research, another exam was carried out, similar to the PET test for A2 level (post-test) according to the course's objectives. The same exams were applied to both groups that included the Part One of the PET, regarding speaking section, with the production of interactive dialogues. The PET tests are internationally recognized, so it guarantees its validity and reliability.

The evaluation of the students in each class also constituted a tool for learning, by increasing their attention and concentration on the contents (Weeden et al., 2002). The evaluation took on special characteristics when the student appeared as evaluator of his 
own work based on a reflection of the group about the learning achieved (Beltrán, 2017), (García-Sanz, 2020). This was also a factor which encouraged communication. Leaders were selected by work teams, to facilitate the organizational work of the teacher and encourage the leading and active role of the student in their learning. Independent team work was oriented to be presented the next meeting.

The variables used in the research were pronunciation, fluency, vocabulary, interaction with the group and accuracy. These are the sub-skills that constitute the main factors that influence the speaking skill (Beltrán, 2018), (Chiroque, 2020), (Leong \& Masoumeh, 2017). Therefore, they were taken as indicators for the evaluation. Students were assessed without prior knowledge of the test's content.

The grades obtained by the students were counted and expressed in percentages in relation to the total and as a rubric average. The results achieved by the students in both tests were compared to determine the effectiveness of the application of the communicative approach in the development of communicative skills.

\section{Materials and Information Communication Technologies (ICT).}

The classes were developed on line way due to the needs imposed by the Covid-19 pandemic.

Information and communication technologies (ICT) were used to carry out distance meetings and contacts, as well as to send the necessary didactic material to students of both groups and interact with them. Regarding the use of hardware, available computers and mobile devices were used. The digital platforms Google Classroom and Cambridge, Messenger and WhatsApp were used as software.

WhatsApp and Messenger have communication channels such as chat between two people or in a group, video calls and documents sending (Ministry de Education of Chile, 2020). It is accessed by mobile phones. The use of digital platforms has proven to be quite useful to encourage motivation among the students. (Sung et al., 2016), (Kim et al., 2016).

Google Classroom integrates with other Google tools like Google Docs and Drive and enables online collaboration. Its access is free (Ministry of Education of Chile, 2020). It facilitates the work of the teacher and the development of oral and written skills in the production of the language, since it offers a variety of resources for that (Rivera, 2020), (Lorenzo, 2019). Teachers can send messages, share videos, documents, web pages, assignments, follow students in their activities, evaluate them in real time, and interact with students and other teachers. Besides, it has a mobile application, which facilitates online exchange and communication (Lorenzo, 2019).

The classes were supported by teaching materials. Digital text material was used for both groups. The Cambridge platform, world renowned in the context of teaching English, was also used (Castro et al., 2016). This platform offers materials for learning English at all levels and allows students to prepare themselves for the internationally valid certification exams (Hilinger \& Pérez, 2019). It provides students and teachers, with appropriate books 
and interactive and motivating channels. Besides, it facilitates the study of the language through monitoring and teacher guidance, making it a useful tool for teaching English in schools at any educational level.

\section{Bibliographic research.}

A bibliographic review of scientific articles, books, papers and thesis was also carried out with the support of Google Scholar, to search for criteria and results of similar research in order to compare different criteria.

The research was carried out using the keywords and related topics. Documents published as of 2016 and recognized authors were preferred. Besides, the incorporation of national bibliography allowed gaining knowledge of the problem within the country.

Over 161 documents were reviewed, out of which, 42 were chosen as bibliographic references based on their contribution to the objective's achievement. The reference lists of the consulted authors also served to locate updated and interesting documents.

Mendeley Desktop was used for the organization and management of bibliography, as well as for the analysis of the information.

The analysis and synthesis of the results allowed verifying a higher level of oral expression skills inside the experimental group.

\section{Results and discussion.}

The results of the pre-test and post-test of the students and grade average by each study group appears on the tables 2 and 3.

In order to simplify the organization of the data, the students who achieved the same score in each sub-skill and the same total score, were regrouped in the same position within the table.

Table 2. Pre-test results for the experimental and control groups.

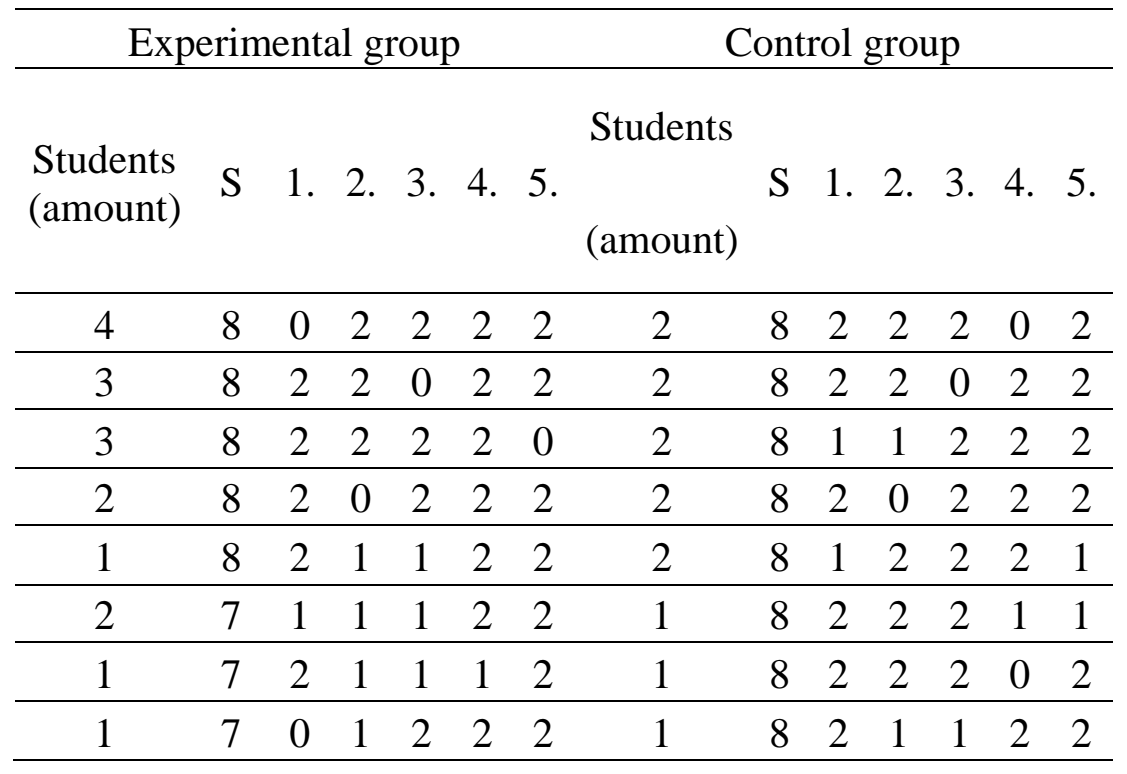


Table 2. Pre-test results for the experimental and control groups. (continuation)

\begin{tabular}{|c|c|c|c|c|c|c|c|c|c|c|c|c|c|}
\hline \multicolumn{7}{|c|}{ Experimental group } & \multicolumn{7}{|c|}{ Control group } \\
\hline $\begin{array}{l}\text { Students } \\
\text { (amount) }\end{array}$ & $\mathrm{S}$ & 1. & 2. & 3. & 4. & 5. & $\begin{array}{l}\text { Students } \\
\text { (amount) }\end{array}$ & $\mathrm{S}$ & 1. & 2. & 3. & 4. & 5. \\
\hline 1 & 7 & 2 & 2 & 1 & 1 & 1 & 2 & 7 & 1 & 2 & 2 & 1 & 1 \\
\hline 1 & 7 & 1 & 2 & 1 & 1 & 2 & 2 & 7 & 2 & 2 & 1 & 1 & 1 \\
\hline 4 & 6 & 1 & 1 & 2 & 1 & 1 & 1 & 7 & 1 & 1 & 2 & 1 & 2 \\
\hline 2 & 6 & 1 & 1 & 1 & 1 & 2 & 1 & 7 & 0 & 2 & 2 & 1 & 2 \\
\hline 2 & 6 & 1 & 2 & 1 & 1 & 1 & 1 & 7 & 2 & 1 & 2 & 0 & 2 \\
\hline 1 & 6 & 1 & 1 & 1 & 2 & 1 & 1 & 7 & 0 & 2 & 2 & 2 & 1 \\
\hline 1 & 6 & 2 & 1 & 1 & 1 & 1 & 2 & 6 & 1 & 1 & 2 & 1 & 1 \\
\hline 1 & 6 & 2 & 2 & 1 & 1 & 0 & 2 & 6 & 0 & 1 & 2 & 2 & 1 \\
\hline 1 & 6 & 2 & 2 & 0 & 0 & 2 & 1 & 6 & 1 & 1 & 1 & 2 & 1 \\
\hline 1 & 6 & 2 & 0 & 2 & 1 & 1 & 1 & 6 & 1 & 1 & 2 & 0 & 2 \\
\hline 1 & 6 & 2 & 2 & 2 & 0 & 0 & 1 & 6 & 1 & 2 & 2 & 1 & 0 \\
\hline 10 & 5 & 1 & 1 & 1 & 1 & 1 & 1 & 6 & 1 & 1 & 1 & 1 & 2 \\
\hline 1 & 5 & 0 & 1 & 1 & 2 & 1 & 1 & 6 & 1 & 2 & 2 & 0 & 1 \\
\hline 1 & 5 & 0 & 2 & 2 & 1 & 0 & 1 & 6 & 0 & 2 & 2 & 2 & 0 \\
\hline 1 & 5 & 1 & 2 & 0 & 1 & 1 & 1 & 6 & 1 & 2 & 1 & 0 & 2 \\
\hline \multirow[t]{7}{*}{1} & 4 & 1 & 1 & 1 & 1 & 0 & 1 & 6 & 0 & 1 & 1 & 2 & 2 \\
\hline & & & & & & & 9 & 5 & 1 & 1 & 1 & 1 & 1 \\
\hline & & & & & & & 1 & 5 & 1 & 1 & 0 & 2 & 1 \\
\hline & & & & & & & 1 & 5 & 1 & 0 & 2 & 1 & 1 \\
\hline & & & & & & & 1 & 5 & 0 & 2 & 0 & 2 & 1 \\
\hline & & & & & & & 1 & 5 & 1 & 2 & 1 & 1 & 0 \\
\hline & & & & & & & 1 & 4 & 1 & 1 & 0 & 0 & 2 \\
\hline
\end{tabular}

Grade

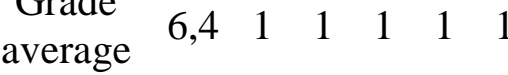

Grade

average

Note: 1.Pronunciation / 2.Fluency / 3.Vocabulary / 4.Interaction / 5.Accuracy / S: Total score.

Source: Pre-test results.

Developed by: The author.

Table 3. Post-test results for the experimental and control groups.

\begin{tabular}{cccccccccccccc}
\hline \multicolumn{1}{c}{ Experimental group } & \multicolumn{1}{c}{ Control group } \\
\hline $\begin{array}{c}\text { Students } \\
\text { (amount) }\end{array}$ & $\mathrm{S}$ & 1. & 2. & 3. & 4. & 5. & $\begin{array}{c}\text { Students } \\
\text { (amount) }\end{array}$ & S & 1. & 2. & 3. & 4. & 5. \\
\hline 2 & 10 & 2 & 2 & 2 & 2 & 2 & 2 & 9 & 2 & 2 & 1 & 2 & 2 \\
\hline 5 & 9 & 1 & 2 & 2 & 2 & 2 & 3 & 8 & 2 & 2 & 2 & 0 & 2 \\
\hline 4 & 9 & 2 & 1 & 2 & 2 & 2 & 2 & 8 & 2 & 2 & 2 & 1 & 1 \\
\hline 3 & 9 & 2 & 2 & 1 & 2 & 2 & 2 & 8 & 1 & 1 & 2 & 2 & 2 \\
\hline 1 & 9 & 2 & 2 & 2 & 2 & 1 & 2 & 8 & 1 & 2 & 2 & 2 & 1 \\
\hline 4 & 8 & 2 & 1 & 2 & 1 & 2 & 1 & 8 & 2 & 0 & 2 & 2 & 2 \\
\hline
\end{tabular}


Table 3. Post-test results for the experimental and control groups. (continuation)

\begin{tabular}{|c|c|c|c|c|c|c|c|c|c|c|c|c|c|}
\hline \multicolumn{7}{|c|}{ Experimental group } & \multicolumn{7}{|c|}{ Control group } \\
\hline $\begin{array}{l}\text { Students } \\
\text { (amount) }\end{array}$ & $S$ & 1. & 2. & 3. & 4. & 5. & $\begin{array}{l}\text { Students } \\
\text { (amount) }\end{array}$ & $\mathrm{S}$ & 1. & 2. & 3. & 4. & 5. \\
\hline 4 & 8 & 1 & 1 & 2 & 2 & 2 & 1 & 8 & 2 & 2 & 1 & 1 & 2 \\
\hline 2 & 8 & 1 & 2 & 1 & 2 & 2 & 1 & 8 & 0 & 2 & 2 & 2 & 2 \\
\hline 1 & 8 & 2 & 1 & 1 & 2 & 2 & 1 & 8 & 2 & 1 & 1 & 2 & 2 \\
\hline 1 & 8 & 2 & 2 & 1 & 2 & 1 & 4 & 7 & 1 & 1 & 2 & 1 & 2 \\
\hline 1 & 8 & 2 & 2 & 1 & 1 & 2 & 3 & 7 & 1 & 2 & 2 & 1 & 1 \\
\hline 1 & 8 & 2 & 2 & 2 & 1 & 1 & 3 & 7 & 0 & 1 & 2 & 2 & 2 \\
\hline 5 & 7 & 1 & 1 & 1 & 2 & 2 & 2 & 7 & 1 & 2 & 2 & 0 & 2 \\
\hline 3 & 7 & 1 & 1 & 2 & 1 & 2 & 1 & 7 & 2 & 2 & 1 & 1 & 1 \\
\hline 3 & 7 & 1 & 1 & 2 & 2 & 1 & 1 & 7 & 2 & 1 & 2 & 0 & 2 \\
\hline 1 & 7 & 2 & 1 & 1 & 2 & 1 & 1 & 7 & 1 & 1 & 1 & 2 & 2 \\
\hline 1 & 7 & 1 & 2 & 1 & 1 & 2 & 1 & 7 & 0 & 2 & 2 & 2 & 1 \\
\hline 1 & 7 & 2 & 1 & 2 & 1 & 1 & 1 & 7 & 0 & 2 & 2 & 1 & 2 \\
\hline 1 & 6 & 0 & 2 & 2 & 1 & 1 & 1 & 7 & 0 & 2 & 1 & 2 & 2 \\
\hline 1 & 6 & 1 & 2 & 1 & 1 & 1 & 2 & 6 & 1 & 1 & 2 & 1 & 1 \\
\hline 1 & 6 & 1 & 1 & 1 & 2 & 1 & 1 & 6 & 1 & 2 & 2 & 1 & 0 \\
\hline \multirow[t]{5}{*}{1} & 5 & 1 & 1 & 1 & 1 & 1 & 1 & 6 & 1 & 1 & 1 & 2 & 1 \\
\hline & & & & & & & 1 & 6 & 1 & 1 & 2 & 0 & 2 \\
\hline & & & & & & & 7 & 5 & 1 & 1 & 1 & 1 & 1 \\
\hline & & & & & & & 1 & 5 & 1 & 0 & 2 & 1 & 1 \\
\hline & & & & & & & 1 & 5 & 1 & 1 & 1 & 0 & 2 \\
\hline $\begin{array}{l}\text { Score } \\
\text { average }\end{array}$ & 7,9 & 1,4 & 1,4 & 1,6 & 2 & 2 & $\begin{array}{c}\text { Score } \\
\text { average }\end{array}$ & 7 & 1,1 & 1 & 2 & 1 & 1,5 \\
\hline
\end{tabular}

Note: 1.Pronunciation / 2.Fluency / 3.Vocabulary / 4.Interaction / 5.Accuracy / S: Total score.

Source: Pre-test results.

Developed by: The author.

Students at the end of the first-year in Bachelor Education must be classified within the A1 level of English, which means that they are able to understand and use simple expressions and phrases from social life, with which they satisfy immediate communication needs and interact in an elemental way (Castro et al., 2016), (Quiñonez, 2016). However, Figure 1 shows the results of the diagnostic test (pre-test) that indicated that more than $50 \%$ of the students did not reach the minimum necessary level. In addition, there were no results within the excellent category. The data shows a similar level in both groups. 
Figure 1. Pre-test results for the experimental and control groups regarding the speaking skill, expressed in percentages in relation to each group.

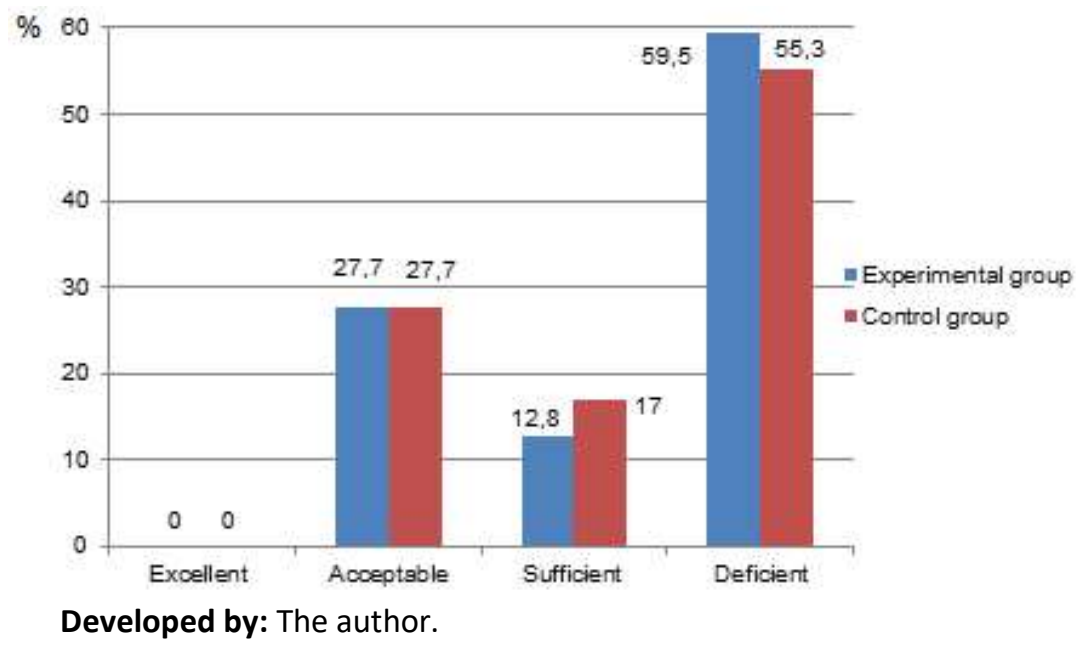

Table 4 shows the results of the pre-test regarding the communication sub-skills.

Table 4. Pre-test results for the experimental and control groups communicative skills, expressed in percentages in relation to each group.

\begin{tabular}{ccccccccccc}
\cline { 2 - 10 } & \multicolumn{10}{c}{ Communication sub-skills (\%) } \\
\cline { 2 - 11 } & Pronunciatio & \multicolumn{1}{c}{ Fluency } & \multicolumn{1}{c}{ Vocabulary } & Interaction & Accuracy \\
\cline { 2 - 10 } & EG & CG & EG & CG & EG & CG & EG & CG & EG & CG \\
\cline { 2 - 10 } With skill & 34 & 25,5 & 40,4 & 42,6 & 36,2 & 53,2 & 38 & 36,2 & 38 & 38,3 \\
\hline Low skill & 51,1 & 59,6 & 53,2 & 51 & 53,2 & 36,2 & 57 & 46,8 & 47 & 55,3 \\
\hline Without skill & 14,9 & 14,9 & 6,4 & 6,4 & 10,6 & 10,6 & 4,3 & 17 & 15 & 6,4 \\
\hline
\end{tabular}

Note: EG: Experimental group / CG: Control group.

Developed by: The author.

Although there are differences in the data for each group, their abilities are quite similar, it which can be classified from medium to low. The homogeneity in both groups provides a favorable starting point for making the comparisons at the end of the post-test.

At the end of the school year, students must reach A2 level, which involves, being able to understand simple and everyday tasks, such as giving basic personal and family information, explained their background, to shop, talking about places of interest, occupations and environmental description (Castro et al., 2016), (Quiñonez, 2016).

Figure 2 shows the results of the post-test, in which both groups showed that they had improved their skills compared to the initial test. 
Figure 2. Post-test results for the experimental and control groups regarding speaking skill, expressed in percentages in relation to each group.

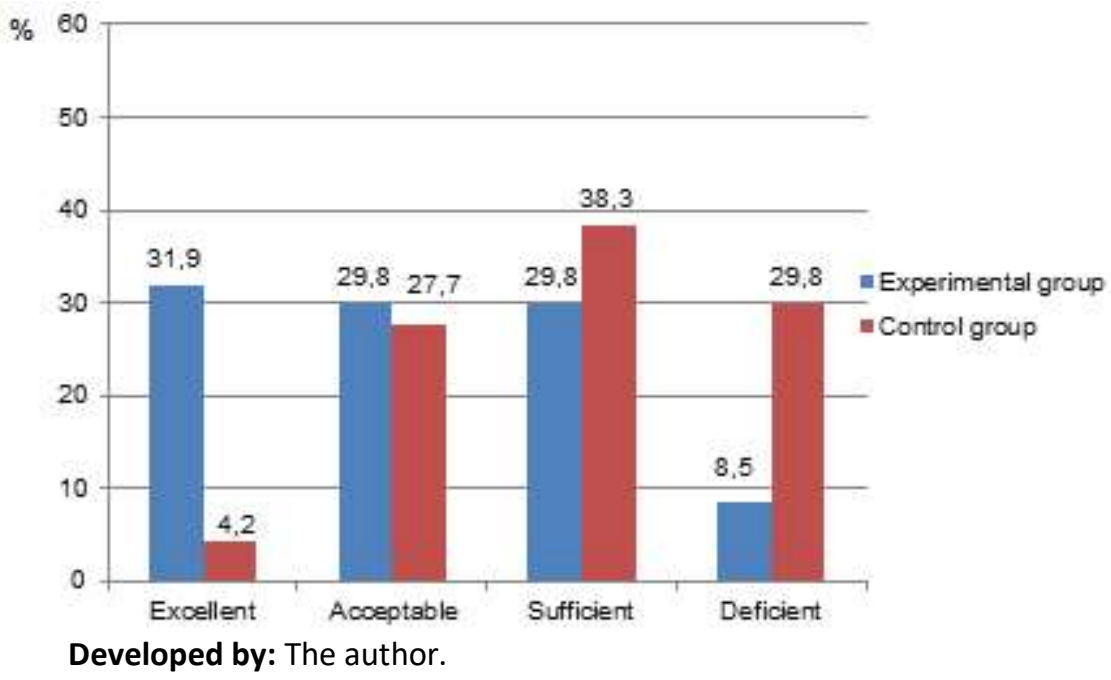

But the experimental group performed better than the controlled group. The results of the post-test for the experimental group indicated the fulfillment of these objectives in 91,5 $\%$ of the students. However, in the control group only 70, $2 \%$ of students achieved the A2 level, and they were not fulfilled in $29,8 \%$, who obtained deficient. This demonstrates the effectiveness of the communicative approach and its methods for the development of speech skills in students. In the experimental group, the students that were graded as excellent show a slightly higher percentage than those of the other categories and the number of students evaluated with deficient decreased notably, like in other investigations (Marañón et al., 2018). However, in the research carried out by Carrera and Saulo, the students evaluated as excellent did not exceed $10 \%$ in both groups (Carrera \& Saulo, 2015). In the rest of the items, the results are similar, especially in regard to the significant reduction of students evaluated with deficiency in the experimental group (Carrera \& Saulo, 2015), (Marañón et al., 2018).

Table 5 shows the results in the post-test, in relation to the communication sub-skills achieved by the students.

Table 5. Post-test results for the experimental and control groups in relation to the communication sub-skills achieved by the students, expressed in percentages in relation to each group.

\begin{tabular}{ccccccccccc}
\cline { 2 - 11 } & \multicolumn{10}{c}{ Communication sub-skills (\%) } \\
\cline { 2 - 11 } & Pronunciation & \multicolumn{1}{c}{ Fluency } & \multicolumn{1}{c}{ Vocabulary } & Interaction & \multicolumn{2}{c}{ Accuracy } \\
\cline { 2 - 11 } & EG & CG & EG & CG & EG & CG & EG & CG & EG & CG \\
\hline With skill & 42,6 & 25,5 & 40,4 & 44,7 & 61,7 & 66 & 70,2 & 34 & 74,5 & 55,3 \\
\hline Low skill & 55,3 & 59,6 & 59,6 & 51,1 & 38,3 & 34 & 29,8 & 49 & 25,5 & 42,6 \\
\hline Without skill & 2,1 & 14,9 & 0 & 4,2 & 0 & 0 & 0 & 17 & 0 & 2,1 \\
\hline
\end{tabular}

Note: EG: Experimental group / CG: Control group.

Developed by: The author. 
Table 6 shows the average obtained by each group in the evaluation skills language in both exams.

Table 6. Rubric average of experimental and control groups, in the pre and post-test.

Rubric:

2. With skill

Rubric average

1. Low skill

\begin{tabular}{|c|c|c|c|c|}
\hline hout skill & $\mathrm{EC}$ & $\mathrm{CC}$ & EG & $\mathrm{G}$ \\
\hline
\end{tabular}

\begin{tabular}{lllllllllll}
\hline Pre text & 1,2 & 1,1 & 1,3 & 1,4 & 1,3 & 1,4 & 1,3 & 1,2 & 1,2 & 1,3 \\
\hline Post text & 1,4 & 1,1 & 1,4 & 1,4 & 1,6 & 1,7 & 1,7 & 1,2 & 1,7 & 1,5 \\
\hline
\end{tabular}

Note: EG: Experimental group / CG: Control group.

Developed by: The author.

The results of the experimental group were superior for all abilities. The controlled group maintained its initial results of pre-test, in terms of pronunciation, fluency and interaction, indicating a lack of training in these aspects.

The increment in vocabulary was the same in both groups. Increase of grammar skills, measured as part of accuracy, was lower in the control group than in the experimental group, despite the fact that these were elements worked on in the classes. This demonstrates the effectiveness of the communicative approach in the development of language skills, above the traditional method. This coincides with the findings of other investigations (Chávez-Choque, 2016), (Arcila \& Velazco, 2016), (Marañón et al., 2018).

Figure 3 shows the average obtained by each group in the evaluation of the five sub-skills in the pre-test and in the post-test.

Figure 3. Trends of rubric average obtained by experimental and control groups, in pretest and post-test.

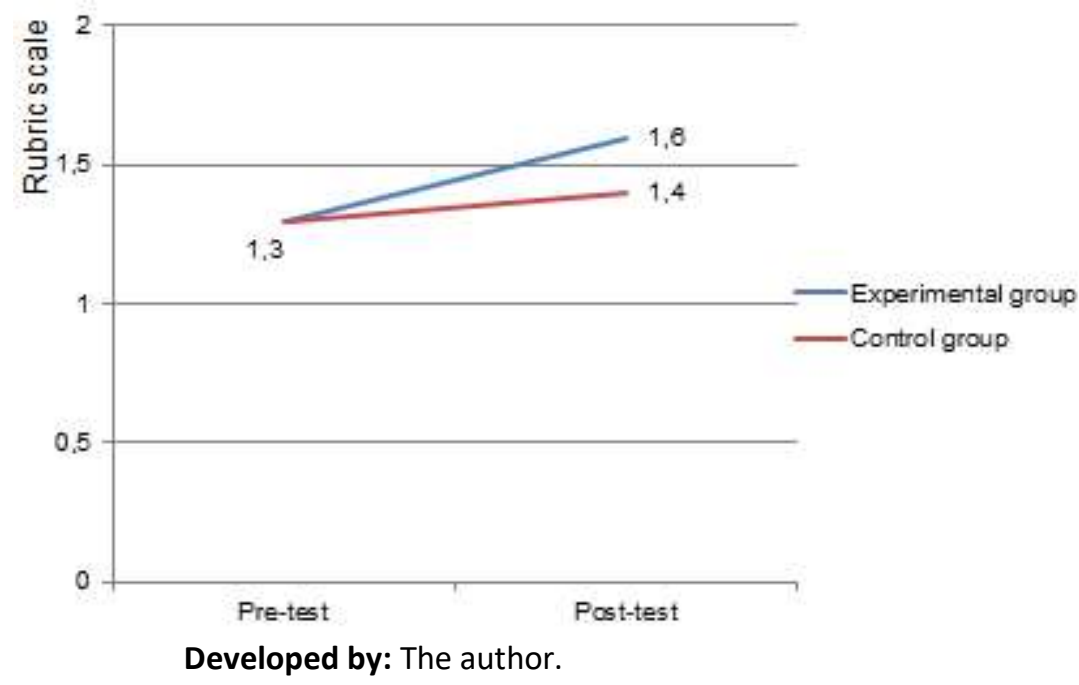

Although both groups improved their results, the increment in communication skills was greater for the experimental group. This same trend appears in the results of similar studies (Chávez-Choque, 2016), (Arcila \& Velazco, 2016). 
If the results achieved by the students of the experimental group at the beginning (pretest) and at the end of the research (post-test) are compared, a radical change is observed in the trend of the curves that describe each of the tests. On Figure 4 it is observed that in the pre-test, the curve becomes zero in the excellent category and is maximized in the deficient category. An opposite behavior occurred in the post-test, where the curve reaches its maximum value in the excellent category and the minimum in the deficient category. The final results were superior in all rubrics for the experimental group, despite the fact that the meetings for communicative activities were not many or frequent, due to the limitations of the course.

Figure 4. Comparison of the results for the experimental group in the pre-test and posttest.

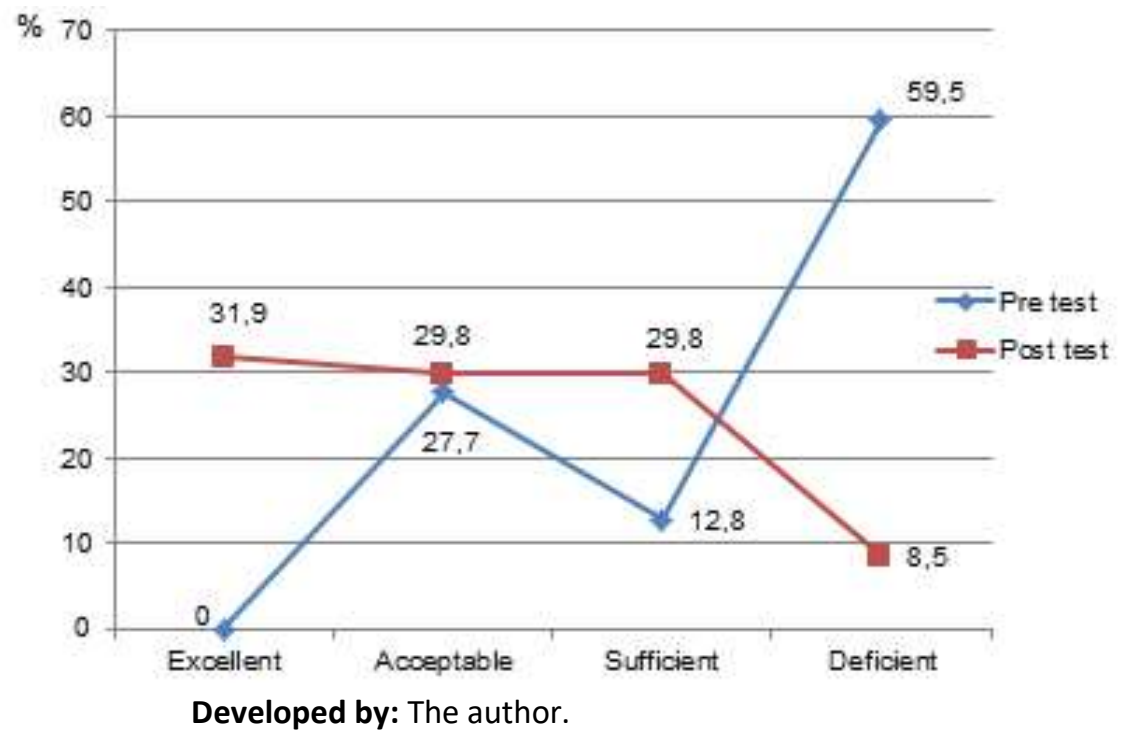

\section{Conclusions.}

- The Communicative Language Teaching and its activities applied were effective to the development of the speaking skill in the second-year of Bachelor Education at Salesian Educational Unit "Santo Tomás Apóstol".

- Communicative language teaching approach introduces principles and objectives that allow the learning process of a language to use classroom activities that best facilitate the development of the communicative competence. The speaking skill is the speaker's communicative competence to transmit coherent and organized oral information, using the sub-skills language to produce a real communication in a real context.

- The CLT activities applied, such as the production of dialogues, role plays and information-gap activities, based on group work and task work, were effective to develop the speaking skill. That was verified for the good results achieved in the communication skills by the experimental group.

- The students' response towards communicative language teaching activities was favorable because it increased their motivation and oral expression skill. 


\section{Bibliographic references.}

Abreus, A. \& Haro, R. (2019). Use of authentic audiovisual materials for speaking skills development: A case study in Ecuador. Revista de Educación Mediática y TIC, 8(1), 23-35. https://doi.org/https://doi.org/10.21071/edmetic.v8i1.10695

Almanza, E., García, M. \& Jiménez, Y. (2019). Developing and evaluating university students discursive competence: a training strategy for teachers. Transformación, 15(3), 424-435. http://scielo.sld.cu/scielo.php?pid=S2077$29552019000300342 \&$ script=sci_arttext $\&$ tlng $=$ en

Arcila, K. \& Velazco, S. (2016). Influence of the task approach in the development of the comprehension and oral expression capacities of the English language of the students of the first year «A» of Secondary of the Educational Institution Manuel González Prada of Chimbote. [Diploma Paper, Universidad Nacional del Santa]. http://repositorio.uns.edu.pe/handle/UNS/2882

Aristizabal, P., Marín, J. \& González, J. (2020). Vivential tasks as didactic strategy in teaching english. Revista Boletín REDIPE, 9(5), 209-220. https://revista.redipe.org/index.php/1/article/view/989

Barrera, H. \& Barragán, T. (2017). English-spanish linguistic competences in ecuadorian educative system. Revista Electrónica Formación y Calidad Educativa, 5(2), 33-42. http://refcale.uleam.edu.ec/index.php/refcale/article/view/1596

Beltrán, M. (2017). English learning as a foreing language. Boletín virtual, 6(4), 91-98. https://revista.redipe.org/index.php/1/article/view/227

Beltrán, M. (2018). Design of a didactic strategy to develop oral skills at unified general high school. Editorial 3 Ciencias Área de Innovación y Desarrollo, SL.

Calderón, J. \& Alzamora, L. (2018). Research designs for postgraduate thesis. Revista Peruana de Psicología y Trabajo Social, 7(2), 71-76. https://doi.org/10.32544/psicologia.v7i2.660

Carrera, G. \& Saulo, J. (2015). Productive skills development in English language of college students. Revista Electrónica Formación y Calidad Educativa, 3(3), 89-109. http://www.refcale.uleam.edu.ec/index.php/refcale/article/view/431

Castro-Miranda, G., Parra, J. \& Calzadilla, G. (2018). The communication is a management competence at education: a look from the ICT teaching-learning $\begin{array}{llll}\text { process. } & \text { RITI } & \text { Journal, } & \text { 48-54. }\end{array}$ https://www.riti.es/ojs2018/inicio/index.php/riti/article/view/86/0

Castro, Y., Abreus, A. \& Hernández, P. (April 11-13, 2016). Perspectives for teaching english at Higher Education Institutes in Ecuador. [Paper] II International Congress of Pedagogic Sciences, Guayaquil, Ecuador. https://www.pedagogia.edu.ec/public/docs/Comision_10/perspectivas_para_la_ens 
enanza_del_ingles.pdf

Chávez-Choque, L. (2016). Communicative competence developing oral expression in English to students of a Higher Education. [Master's Thesis, Universidad César Vallejo]. https://repositorio.ucv.edu.pe/handle/20.500.12692/7609

Chávez, M., Saltos, M. \& Saltos, C. (2017). The importance of learning and knowledge of the English language in Higher Education. Dominio de las Ciencias, 3, 759-771. https://doi.org/10.23857/dc.v3i3

Chiroque, C. (2020). English teacher's criteria about teaching grammar from the communicative approach, at the secondary level of public schools in the district of Piura. [Diploma Paper, Universidad de Piura]. https://pirhua.udep.edu.pe/handle/11042/4645

Escalona, E., Frías, Y. \& Fonseca, M. (2020). Cooperative learning as a procedure for developing the english communicative competence in the cuban educational system. Encuentro, Revista del Departamento de Filología Moderna, 28, 3-16. https://dialnet.unirioja.es/servlet/articulo?codigo=7342628

Fabre, P., Calero, J. \& Albán, J. (2016). Impact of the differentiated education in the teaching of english as a foreing language in the Ecuador. Didáctica y Educación, VII(2), 109-122. http://revistas.ult.edu.cu/index.php/didascalia/article/view/479

Farabi, M., Hassanvand, S. \& Gorjian, B. (2017). Using guided oral presentation in teaching english language learners' speaking skills. Journal of Applied Linguistics and Language Learning, 3(1), 17-24. https://doi.org/10.5923/j.jalll.20170301.03

Fuertes, B. (2017). Synergy of main active methods for the communicative competence in English language. Case: students from the Language Center of the Faculty of Health Sciences of the National University of Chimborazo. [Doctoral Thesis, Universidad Nacional Mayor de San Marcos]. http://cybertesis.unmsm.edu.pe/handle/20.500.12672/5677

García-Sanz, E. (2020). Assessment of the own progress in oral communication skills vs the importance given to self-assessment criteria. Lenguaje, 48(1), 38-59. https://doi.org/10.25100/lenguaje.v48i1.6571

Halbach, A. (2019). English in CLIL times: a propousal for a new methodology to English classes. Padres y maestros, 387, 6-10. https://doi.org/10.14422/pym.i378.y2019.001

Hilinger, A. \& Pérez, V. (2019). Comparative analysis and evaluation of the quality of electronic resources to learn foreing languages: The case of Cambridge English and Aveteca. Revista de Educación Mediática y TIC, 8(1), 36-54. https://doi.org/https://doi.org/10.21071/edmetic.v8i1.11156

Kim, K., Hwang, J. \& Zo, H. (2016). Understanding's users continuance intention toward smartphone augmented reality applications. Sage Journals, 32(2). 
https://journals.sagepub.com/doi/abs/10.1177/0266666914535119

Leong, L. \& Masoumeh, S. (2017). An analysis of factors influencing learner's english speaking skill. International Journal of Research in English Education, 34-42. www.ijreeonline.com

Loor, L., Palma, M., Saltos, L. \& Bolívar, O. (2018). Cooperative learning strategy to teach English language in the public schools of Ecuador. Dominio de las Ciencias, 4(3), 431-448. https://doi.org/10.23857/dc.v4i3.817

Lorenzo, B. (2019). Google Classroom: a teaching tool to reading comprehension and written expression skills in English. [Master's Thesis, Universidad de la Laguna]. https://riull.ull.es/xmlui/bitstream/handle/915/17304/Google Classroom como herramienta didactica para trabajar las destrezas de comprension lectora y de expresion escrita en ingles.pdf?sequence $=1$

Marañón, D., González, M., Álvarez, M. \& Cañizares, N. (2018). Practical activities to improve oral expression in english for medicine students. Panorama Cuba y Salud, 13(Especial), 375-379. https://journals.sagepub.com/doi/abs/10.1177/0266666914535119

Ministry of Education of Chile. (2020). General orientations to guide learning's students for distance modality in Higher Education Institutes. Indications to the Actions Plan for Covid-19. Chile Goverment. https://bibliotecadigital.mineduc.cl/bitstream/handle/20.500.12365/14670/

Nofuentes, M. (2019). Methodological approaches in the teaching of English as a foreign language. Intervention proposal: task approach and CLIL.

[Diploma Paper, Universidad de Valladolid], 2018-2019. https://core.ac.uk/reader/250407290

Oxford, R. (2001). Integrated skills in the ESL / EFL classroom. ESL Magazine, 6(1). https://files.eric.ed.gov/fulltext/ED456670.pdf

Parrales, M., Sornoza, D., Cano, R. \& Moreira, M. (2018). A look about communication in Higher Education. Polo del Conocimiento, 3(6), 277-289. https://doi.org/10.23857/pc.v3i6.525

Pinto, A. (2019). Determination of the most effective method for teaching English as a foreign language in speaking ability for Colombian adolescents from the comparative analysis of the four most used methods. [Specialization's Thesis, Universidad Nacional Abierta y a Distancia, Pamplona]. https://repository.unad.edu.co/handle/10596/26308

Quiñonez, J. (2016). Communicative approach to teaching English as a foreign language.

[Master's Thesis, Pontificia Universidad Católica del Ecuador, Sede Esmeraldas]. 
https://repositorio.pucese.edu.ec/handle/123456789/616

Reyes, S., Robayo, J., Sánchez, A., Torres, Y. \& Guarnizo, F. (2020). Continuing education strategy to improve the practices of teaching English as a foreing language through the CLIL approach in the first grade of elementary school at the San Isidoro Educational Institution. La revista investigación, desarrollo, educación, servicio, trabajo, $1(1)$, $62-73$. http://www.revista.fundes.edu.co/index.php/revista/article/view/5

Richards, J. (2006). Communicative language teaching today. Cambridge University Press.

Richards, J. \& Rodgers, T. (2014). Approaches and methods in language teaching. Cambidge University Press.

Rivera, M. (2020). Using Google Classroom platform to oral and written skills promotion in L2 (English) of third grade students in a public educational institution.

[Master's Thesis, Universidad del Norte, Barranquilla]. http://manglar.uninorte.edu.co/handle/10584/9268\#page=1

Sánchez, J. \& Pérez, O. (2020). Communicative approach in the teaching-learning process of english as a foreign language. Revista ConCiencia EPG, 5(2), 1-14. https://doi.org/https://doi.org/10.32654/CONCIENCIAEP

Sung, Y., Chang, S. \& Liu, T. (2016). The effects of integrating mobile device whith teaching and learning on student's learning performance. A meta- analysis and research synthesis. Elsevier Computers \& Education, 94, 252-275. https://www.sciencedirect.com/science/article/pii/S0360131515300804

Toro, V., Camacho, G., Pinza, E. \& Paredes, F. (2019). The use of the communicative language teaching approach to improve students' oral skills. English Language Teaching, 12(1), 110-118. https://doi.org/10.5539/elt.v12n1p110

Veloz, L. \& Mancero, W. (2017). A look at teaching and learning of English language. Polo del Conocimiento, 2(4), 203-212. https://doi.org/10.23857/pc.v2i4.275

Weeden, P., Winter, J. \& Broadfoot, P. (2002). Assessment, What's in it for school? Routledge Falmer.

Willis, D., \& Willis J. (2013). Doing Task-based Teaching. Oxford University Press.

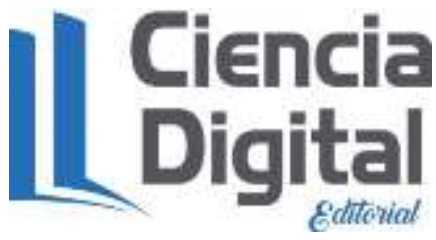




\section{PARA CITAR EL ARTÍCULO INDEXADO.}

Oviedo Guado, N. G., \& Mena Mayorga , J. I. (2021). Communicative language teaching approach in the development of speaking skill. Ciencia Digital, 5(4), 6-26. https://doi.org/10.33262/cienciadigital.v5i4.1865

\section{ULiencia}

El artículo que se publica es de exclusiva responsabilidad de los autores y no necesariamente reflejan el pensamiento de la Revista Ciencia Digital.

El artículo queda en propiedad de la revista y, por tanto, su publicación parcial y/o total en otro medio tiene que ser autorizado por el director de la Revista Ciencia Digital.
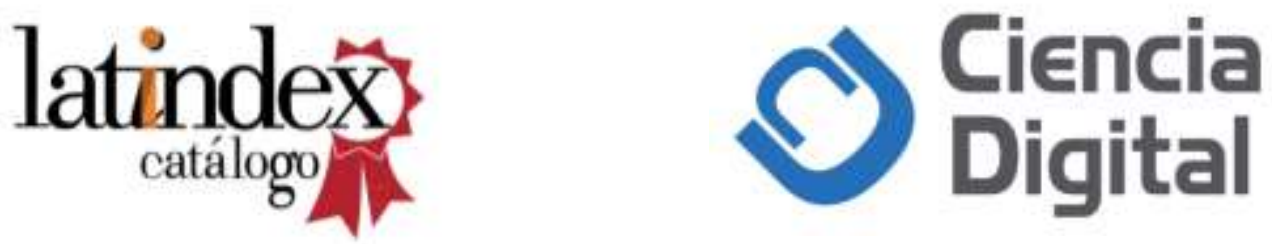